\title{
مَ \\ Lanzamiento del «Programa Cátedra OMC» en el Instituto de Estudios Internacionales. Discurso del Director General de la Organización Mundial del Comercio
}

Pascal Lamy. Santiago, 15 de abril de 2010

It is a great pleasure for me to be with the University of Chile today to launch the WTO Chair at the Institute of International Studies.

Allow me first to express, on behalf of the WTO family as well as myself, our sincere condolences to the Chilean people for the immense personal and material losses suffered by your country as a result of the tragic earthquake in February. In these difficult times, those qualities which have traditionally characterized the Chilean people - courage and collective solidarity, together with the integrity of your solid institutions - will no doubt facilitate the task of rebuilding infrastructure and bringing back the economic and social dynamism of the Chilean society.

These are the same values that Chile has brought to the World Trade Organization, of which this country is an active and constructive Member. By engaging actively and continuingly in the work of our Organization, including chairing our last Ministerial Conference, last December, Chile has once again demonstrated its commitment to the strengthening of the multilateral trading system.

In a few minutes we will be officially opening the WTO Chair. The fact that the WTO has established a chair at the 
Institute of International Studies of the University of Chile pays tribute to the history of this institution and its commitment to knowledge and science.

We conceived the WTO Chairs Programme in 2009, when the global economic crisis was at its worse. And this is no coincidence. The crisis was indeed a manifestation of global challenges which are testing the capacity of the international system to address them. This highlighted the crucial role of global cooperation and governance to restore growth and employment.

The adverse impact of the crisis on the world economy in terms of output and employment is undeniable. This has been the first crisis of a truly global nature; a crisis which has severely affected international trade. Indeed, the collapse in demand resulting fron the financial crisis led to a trade contraction of around $12 \%$ last year, a far bigger contraction than the shrinkage of trade in the Great Depression.

Whether in big or small economies, ranging from OECD economies to single commodity economies in the Caribbean, the effects of the crisis have been devastating. Of course, while no economy has been spared, it is developing countries, particularly the least developed amongst them, that have more acutely felt its full impact. This is because these are countries whose ability to fight the crisis is more limited, given their limited financial resources - they cannot afford multi billion dollar stimulus packages to bail out struggling enterprises and therefore they are very much more at the mercy of the global economic system for their recovery.

The family of the international organizations, and we in the WTO, have taken steps to minimise the impact of the crisis, bearing in mind the high trade dependence of many developing country economies.

First, we have worked to keep trade flowing, by mobilising efforts into trade finance, the oil that keeps the wheels of trade moving. Second, we have helped WTO Members fight against protectionist pressures by ensuring transparency in the measures taken by each of them to respond to the crisis. Thirdly, we have continued to mobilise international support towards developing countries to boost their production and improve their trade capacity through increased Aid for Trade. 
We started last year with a collapse in trade, a drying up of trade finance, serious concerns that donors would reduce funding for Aid for Trade, and worries that protectionism would kick in. And yet over one year from the onset of the crisis, we see that, to this point at least, the multilateral trading system has proven its sturdiness as a bulwark against high intensity protectionism.

If we look at what happened in the 30's, we will discover that a protectionist trade response prolonged and deepened the depression, which as we all know became the prelude to the World War. This time, governments have so far shown considerable restraint and have largely if not totally kept markets open. I say «so far» because I do not believe we are out of the woods yet. In fact, even if we are seeing a return to growth and even if the forecast for world trade in 2010 is positive, the levels of unemployment worldwide remain extremely high. Unacceptably high. And this will continue to create pressures at home for protectionist measures.

In many economies, especially developed countries, stimulus packages have been instrumental in preventing further deterioration in output while paving some way to recovery, even at the cost of inflating public deficits. Unlike rich countries, developing countries have not all been able to provide huge bailout packages to their ailing industries and expand social safety nets to those who have lost their jobs. Hence, economies, both developed and developing, urgently need other sources of growth - sustainable engines of growth. This is where trade can be an important part of the recovery story, in the long-run as well as in the short to medium-term.

Trade is the stimulus package available to both developed and developing countries. It has to be part and parcel of the economic recovery effort for growth to be sustainable. Our forecast for 2010 shows trade growing by $9,5 \%$, around which is a mixture of $11 \%$ for developing economies and around $7 \%$ for developed ones.

In the long-run, economic growth is driven very significantly by technological progress and by the quality od domestic institutions. And trade has an important role in this context. 
First, it can enhance technological progress by increasing the incentives to innovate, facilitating transfer of technology and fostering «learning-by-doing» effects.

Second, trade reform may directly increase the quality of institutions by leading to the adoption of certain institutional norms or standards. Moreover, the preferences that underlie such institutional reforms may be the indirect consequence of the workings of market forces associated with trade.

In the short-to-medium term, trade allows external demand to provide a buffer for economies facing low domestic demand during periods of recovery from the crisis. This is especially important in economies where domestic demand is likely to be subdued for a while, as domestic savings are reconstituted and as the financial system recovers. Trade openness vis-à-vis a diverse set of countries is important for mediating the effect of a shock.

More generally, trade can increase income or output levels through efficiency gains from specialization based on comparative advantages, greater competition, by access to a larger variety of intermediate inputs, by scale economies and by an intra-industry reallocation of resources.

As a digression, it is also worth noting that trade may help keep prices of goods down as economies recover from the crisis. This means that prices will not increase as much in response to an increase in output or a reduction in unemployment when economies are open to trade, because trade allows countries to source important godos or inputs from the rest of the world.

Today, the most efficient means for countries to use trade as an engine for recovery remains the conclusion of the Doha Development Round, the multilateral round of trade negotiations launched in 2001. Whether it is about generating market acces for goods and services through the reduction of obstacles to trade, or levelling the playing field in trade distorting subsidies - whether to agriculture or to fisheries - or providing predictability and transparency to trade or even by facilitating trade by cutting read tape, the Doha Round offers untapped opportunities that the global community cannot afford to miss.

Still, while trade opening is crucial in times of recovery, countries need to have appropriate infrastructures and they need to 
implement adequate macroeconomic policies in order to reap the benefits from international trade. Proper trade rules and adequate domestic policies are the two necesary ingredients for a successful trade policy, one that creates growth, development and employment. Trade capacity building is part of this mix. This is why, much as this University is devoted to high level education, at the WTO we also recognize the importance of technical assistance and training activities as one of our core activities.

Through its technical assistance and training programmes, the WTO delivers a variety of activities which seek to enhance the quality and level of participation of our developing-country Members in the functioning of the system. Such activities are also aimed at assisting developing countries in the implementation of their WTO commitments, providing training for government officials on trade policy-related matters and on the WTO Agreements.

As we gain experience in providing technical assistance, it has become clear to us that we should involve national academic institutions as partners in our endeavours. Academic institutions have helped us raise awareness on trade issues and also facilitated the participation of civil society in the debate of such issues, so that decision-making processes and their corresponding results have the necessary legitimacy. The role of academic instituttions is also essential in creating capacity at home through local academic and training programmes. That is why we decided to embark on programmes of academic support for capacity building.

With the support of WTO Members, we gradually structured a set of programmes aimed at contributing to the development and strengthening of capacities in academic institutions in the field of trade policy, trade law and WTO- related issues. These regional or national activities aim at familiarizing the academic communities with the functioning of the multilateral trading system and the specificities of WTO Agreements. They also help in the analysis and discussion of relevant topics and concerns for trading communities. These programmes also create bridges among and between scholars around the world and the WTO Secretariat.

So we seek to transfer ownership to partner institutions and supporting programmes that have a long-term perspec- 
tive and that are sustainable over time, possessing an intrinsic multiplying impact. In the end, the WTO Secretariat recognizes that Geneva can only contribute in a marginal way, as it only possesses very limited resources. It is only through national universities and research centres, such as the Institute of International Studies, that the population at large can access academic education, and that specialized trainig for trade officials in particular can be effectively provided.

In 2009, we launched the WTO Chairs Programme, which aims at supporting academic institutions and associated individual scholars from developing countries in course preparation, teaching, research and outreach activities. Fourteen chairs were allocated on the basis of a competitive bidding process. While we provide direct support to academic institutions from developing countries, the participation in the WTO Chairs Programme is open to scholars and academic instituttions from developed countries as well. Our final aim is to create a network of academic and research institutions to share knowledge and experience.

The WTO Chairs Programme provides financial support for a period of four years to beneficiary institutions, and facilitates continuous interaction between such institutions and with their homologues and other think tanks around the world. It will provide students, civil society and other stakeholders with a deeper understanding of trade policy issues, disseminate research and information, promote discussion on international trade and trade cooperation, and also provide analytical input into the formulation and implementation of trade policy.

During 2009 we also launched a WTO Essay Award for Young Economists. We want to promote research on the WTO related issues among young economists, and to reinforce the relationship between the WTO and the academic community. I would like to take this opportunity to encourage the many students among you to participate in this competition by submitting the fruits of your research.

The WTO and the Institute of International Studies of the University of Chile have worked together for several years. Both institutions have collaborated in the delivery of three Regional Trade Policy Courses for trade officials from Latin America, one of our flagship training programmes, under 
the academic coordination of our friend and veteran trade negotiator Francisco Prieto. This collaboration has now been taken to another level through the establishment of the WTO Chair at the Institute.

Having a solid background in research on international affairs, with a high level of academic performance, reflected in world-class publications in trade-related matters, the Institute has been selected to implement a specific project, as a WTO Chair.

This project will strengthen the Institute's diploma Program in International Strategy and Trade Policy, which will be further developed into a bilingual Masters Degree in International Political Economy and Trade Regime. It will also deliver several short courses on the Multilateral Trading System to the different regions of Chile, as well as courses for Chilean Parliamentarians and conferences, round tables, and meetings of different kinds. I also wish to highlight that the project also envisages granting scholarships to undertake the Diploma Program.

In the field of research, the Institute's project envisages six lines of work which are very pertinent to the trade agenda of the future, such as trade facilitation and trade finance, trade in services or issues related to intellectual property.

I wish to congratulate the Director of the Institute, Professor José Morandé Lavín, and in particular our WTO Chair holder, Professor Dorotea López-Giral, and thank them for their dedication to this programme.

Finally, I have great pleasure to award a WTO Chair to the University of Chile, at its Institute of International Studies. This award is a tribute to the competence of this University and to the dedication of its academics. It is also an encouragment to your researchers and students to take an interest in multilateral trade matters, a cornerstone of international global goverance. I wish you all success in your endeavours. 